\title{
PRONUNCIAMENTO CONJUNTO DAS ENTIDADES DA ÁREA DA EDUCAÇÃO EM RELAÇÃO ÀS DIRETRIZES CURRICULARES NACIONAIS PARA O CURSO DE GRADUAÇÃO EM PEDAGOGIA
}

\begin{abstract}
Pronunciamento conjunto das entidades da área da educação Associação Nacional de Pós-Graduação e Pesquisa em Educação (ANPEd), Associação Nacional pela Formação dos Profissionais da Educação (ANFOPE), Associação Nacional de Política e Administração da Educação (ANPAE), Centro de Estudos Educação e Sociedade (CEDES), Fórum de Diretores das Faculdades/Centros de Educação das Universidades Públicas Brasileiras (FORUMDIR) em relação às Diretrizes Curriculares Nacionais para o Curso de Graduação em Pedagogia.
\end{abstract}

7 homologação das Diretrizes Curriculares Nacionais para o Curso de Graduação em Pedagogia, expressa nos Pareceres CNE/CP n. 5/2005 e 3/2006 e na Resolução CNE/CP n. 1/2006, representa um avanço histórico no campo da formação dos profissionais da educação, em especial, na formação de professores para a Educação Infantil e Anos Iniciais para o Ensino Fundamental e na formação de profissionais para as funções de planejamento, administração, supervisão, inspeção e orientação educacional.

Esse avanço histórico se confirma na medida em que as Diretrizes Curriculares Nacionais para o Curso de Graduação em Pedagogia:

a) Definem de maneira inequívoca que o curso de Pedagogia, enquanto uma licenciatura, constitui-se no lócus privilegiado, ainda que não exclusivo, para a formação de professores para exercer funções de magistério na Educação Infantil e nos anos iniciais do Ensino Fundamental.

b) Definem que essa formação para o exercício do magistério deve articular-se à formação para a produção do conhecimen- 
to em educação e para a gestão educacional, na perspectiva da gestão democrática. Rompe-se, dessa forma, com aqueles modelos fragmentados e aligeirados de formação dos profissionais da educação, fragilizados em torno de habilitações específicas e que dicotomizam a formação do bacharel e do licenciado.

c) Reconhecem e consolidam a produção teórica dos últimos vinte anos no campo da formação de professores, que afirmam a urgência e apontam caminhos para o desenvolvimento de processos formativos que assegurem uma sólida formação teórica, interdisciplinar e que se sustente no trabalho coletivo.

d) Consolidam a experiência histórica construída, principalmente ao longo dos últimos vinte anos, nos Cursos de Pedagogia das Instituições Públicas de Ensino Superior, que em sua maioria desenvolvem processos formativos que articulam, na formação de professores para a Educação Infantil e Anos Iniciais do Ensino Fundamental, a compreensão da educação e da escola em sua multidimensionalidade, na medida em que envolvem o estudo da escola e dos sistemas de ensino, sua organização, estrutura e funcionamento e a formação básica inicial para a pesquisa em educação.

Ao lado desses avanços, as Diretrizes Curriculares Nacionais para o Curso de Graduação em Pedagogia trazem outras importantes contribuições para a melhoria da educação brasileira, ao articular de maneira consistente a formação a ser desenvolvida nesse curso com o que estabelece a Lei n. 9.394/1996. Essa articulação se evidencia em aspectos como:

a) Vincula a formação para a gestão educacional à perspectiva da gestão democrática da educação, como estabelece o princípio expresso no inciso VIII do artigo $3^{\circ}$ dessa Lei.

b) Exige que a formação a ser desenvolvida no Curso de Pedagogia assegure a preparação do professor para o desempenho das atribuições definidas nos artigos 13 e 14 da Lei de Diretrizes e Bases da Educação Nacional, as quais envolvem o desenvolvimento de aptidões que possibilitem aos docentes desempenhar, de maneira sólida e consistente, as funções concernentes à aprendizagem e recuperação dos alunos, às tarefas relativas 
à elaboração da proposta pedagógica da escola, à participação no planejamento, à avaliação e ao desenvolvimento profissional, à articulação da escola com as famílias e a comunidade e à participação nos conselhos escolares.

c) Nos termos do artigo 64 da LDB, reafirma que a formação mínima para o exercício do magistério na Educação Infantil e nas quatro primeiras séries do Ensino Fundamental ocorrerá no Curso de Pedagogia, ao mesmo tempo em que mantém, ainda que de forma inadequada, a possibilidade dessa formação se desenvolver no Curso Normal Superior.

Diante dessas considerações, as entidades signatárias do presente pronunciamento propóem:

a) Duração mínima de quatro anos para os Cursos de Pedagogia, observada a carga horária mínima de 3.200 horas definida nas Diretrizes em análise.

b) Constituição de um Comitê Nacional de Formação dos Profissionais da Educação, composto pelas entidades signatárias e representantes do Ministério da Educação e do Conselho Nacional de Educação, no intuito de acompanhar a implementação das Diretrizes Curriculares Nacionais para o Curso de Pedagogia e propor políticas no campo da formação dos profissionais da educação.

c) Realização de um Seminário Nacional sobre a Formação de Profissionais da Educação nos Cursos de Pedagogia e Normal Superior, convocado pelo Ministério da Educação e sob a organização e coordenação das entidades aqui signatárias.

Brasília, 10 de dezembro de 2006. 